Osoba i doświadczenie mistyczne (2) „Filozofia Chrześcijańska” 14 (2017), s. 37-46

doi: $10.14746 /$ fc. 2017.14 .2

\author{
JAN KROKOS \\ Uniwersytet Kardynała Stefana Wyszyńskiego \\ Wydział Filozofii Chrześcijańskiej
}

\title{
Pastoralny wymiar filozofii
}

Księdzu Profesorowi Antoniemu Siemianowskiemu

Zagadnienie, określone jako pastoralny wymiar filozofii, sytuuje nas w Kościele i w jego zbawczej misji wobec świata, którą ostatnio dokładnie opisał przede wszystkim Sobór Watykański II. Wyznacza je pytanie o potrzebę i znaczenie filozofii (z którą Kościół ani się nie utożsamia, ani jej nie legitymizuje) w pastoralnej posłudze, jaką na różne sposoby spełnia w świecie zawsze mu współczesnym poprzez osoby, realizujące różne powołania, w tym poprzez kapłanów. Uszczegółowieniem tego zagadnienia jest problem roli filozofii w formacji seminaryjnej oraz $\mathrm{w}$ studiach teologicznych. Zagadnienie ma szerszy kontekst. Jest nim miejsce i rola filozofii w kulturze w ogóle, a w nauce - w jej strukturze - w szczególności. Filozofia bowiem, nie jej poszczególne realizacje, lecz ona sama jako rzetelny namysł poznawczy nad podstawami rzeczywistości i jej fragmentów przenika życie każdego człowieka i jego działanie, nawet jeśli nie zostaje stematyzowana, a zatem także życie religijne, chrześcijańskie.

\section{Filozofia a Jezus Chrystus i Jego dzieło}

Pytając o pastoralny wymiar filozofii, musimy najpierw zwrócić się ku dziełu Jezusa Chrystusa. Jest ono bowiem jedynym i pełnym wzorcem dla tej aktywności, którą zwiemy działaniem pastoralnym, duszpasterskim, która obejmuje nauczanie, uświęcanie oraz kierowanie Ludem Bożym (munus docendi, munus sanctificandi, munus regendi). 
Czytając Ewangelie, bez trudu zauważymy, że Chrystus ani nie był filozofem, ani filozofii nie uczył, jeśli obu terminów używamy w sensie akademickim. Jednak jeśli sięgniemy do etymologii terminu: filozof to miłośnik mądrości, to powiemy, że jest On filozofem par excellence. Jeśli sięgniemy do dogmatyki katolickiej, która ukazuje nam Boga jako absolutną Jedność, a więc także jako Mądrość i Miłość, która kocha samego siebie, a więc i Mądrość właśnie; jeśli odwieczna Miłość łączy Ojca i Syna, który miłując Ojca, miłuje Go także jako odwieczną Mądrość, to i Bóg Trójjedyny, i druga Osoba Trójcy Świętej jest miłośnikiem mądrości w sposób przewyższający ziemską postać filozofa.

Na szczęście, poza jednostkowymi wypadkami, np. interpretując starożytne rzeźby nagrobne, nie nazywa się Chrystusa filozofem. Nie można bowiem żadną miarą zrównywać Go z filozofami ani starożytnymi, ani późniejszymi po czasy współczesne. Nie przetrwało też stanowisko Tacjana, ucznia św. Justyna, który uznał chrześcijaństwo za jedynie prawdziwą filozofię, odrzucając jednocześnie całą filozofię grecką jako zbędną i niedorzeczną ${ }^{1}$. Raczej rację przyznaje się Justynowi, który choć był przekonany o doskonałości chrześcijaństwa, w filozofii greckiej dostrzegał zarodki prawdy (spermata), przez co wskazywał, że i chrześcijaństwo może ubogacić się przez filozofię ${ }^{2}$. Dzięki temu obroniona została wyjątkowość Jezusa Chrystusa i Jego dzieła - chrześcijaństwa oraz pluralizm wytworów ludzkiego ducha, pośród których jest i chrześcijaństwo, i filozofia, i nauka, i sztuka itp. ${ }^{3}$

Wnikając w istotę dzieła Jezusa Chrystusa, na pierwszym miejscu należy zauważyć, że dokonał je szczególny podmiot, odwieczny Logos. Każde dzieło niesie w sobie piętno swego twórcy. W szczególności uwidacznia się to w wytworach ducha, także ludzkiego, w wytworach intencjonalnych. Dlatego, w czym będziemy zgodni z myślą teologiczną, zbawienia świata nie mógł dokonać nikt inny, jak Chrystus-Logos, pozostający w komunii Boskich Osób. Znaczy to jednak także, że nie każdy może uczestniczyć w dziele Chrystusa poprzez posługę pastoralną. Może nim być tylko ten, kto będzie cechował się właściwymi temu dziełu przymiotami. Także i ten, który ma przyjąć zbawczy dar Jezusa Chrystusa, musi być odpowiednio do tego przygotowany. Potwierdzeniem jest różnoraka edukacyjna działalność Kościoła, skierowana do tych, którzy aktywnie mają uczestniczyć w posłudze pastoralnej, oraz do tych, ku którym ta posługa jest adresowana. Szczególnym, liturgicznym potwierdzeniem tego jest przyzywanie Ducha Świętego we wszystkich ważnych zbawczo

\footnotetext{
${ }^{1}$ Por. Tacjan, Mowa do Greków, 2, 1-3; 3, 1-7; 25, 1-5; 26, 1-8; 31, 1-6; 32, 1-7, tłum. L. Misiarczyk, w: Pierwsi apologeci greccy, oprac. J. Naumowicz, Kraków 2004.

2 Por. Justyn, Apologia II, 10, 1-5; 13, 1-6, thum. L. Misiarczyk, w: Pierwsi apologeci greccy, dz. cyt.

${ }_{3}^{3}$ Zwracam na to uwagę, gdyż czasy współczesne cechują tendencja unifikacji i totalizmu, mimo haseł o pluralizmie.
} 
wydarzeniach życia chrześcijańskiego, by obdarzył nas sobą, swoimi darami, a wśród skatalogowanych darów Ducha Świętego trzy (dar mądrości, rozumu i umiejętności) wprost odnoszą się do intelektu, a pozostałe (dar rady, męstwa, pobożności i bojaźni Bożej) go zakładają. Łaska buduje na naturze, a zatem trzeba odpowiednio kształcić i kształtować człowieka, w czym doniosłą rolę odgrywa m.in. filozofia, by był zdolny przyjąć zbawcze dzieło Jezusa Chrystusa i wespół z Nim działać.

Dalej - istotnym elementem dzieła Jezusa Chrystusa było nauczanie, a to zakłada rozumność. Chrystus uważał siebie za nauczyciela i tak był spostrzegany przez uczniów i słuchaczy, a nauczając, Chrystus nie tylko przekazywał konkretne prawdy o Bogu i człowieku, lecz także wskazywał na ich podstawę i uprawomocnienie. Nie domagał się od słuchaczy ślepej wiary, lecz wyjaśniał, tłumaczył, argumentował. Jakże często w dialogu ze słuchaczami, a zwłaszcza z faryzeuszami i uczonymi w Piśmie, wskazywał na błąd w myśleniu, jaki popełniają ci, którzy daną prawdę odrzucają (pewna forma „,dowodu nie wprost”). Niekiedy było to wskazanie na błędne rozumienie Pisma czy wręcz na jego nieznajomość, innym razem na błąd rozumowania, jeszcze innym - na niedostrzeganie, jak się rzeczy mają, na ignorowanie rzeczywistości. Przykłady można by mnożyć. Zawiera je Kazanie na górze, w którym Nauczyciel, wskazując na ptaki powietrzne i lilie polne, każe dostrzegać rzeczywistość taką, jaką ona jest, i uzasadnia właściwą hierarchię dóbr (por. Mt 6,19-7,29). W rozmowie z faryzeuszami i uczonymi w Piśmie, a także saduceuszami wykazywał, że ich zasady postępowania uchylają Boże przykazania na rzecz ludzkiej tradycji (por. Mt 15,2-6; Łk 11,37-54), że zasady te są niezgodne ze zdrowym rozsądkiem i rzetelnym oglądem świata (por. Mt 12,11n), że jego adwersarze, broniąc swego stanowiska, wikłają się w sprzecznościach (por. Mt 12,24-26; Mk 3,22-27; Łk 11,14-20).

Wszystko to, a także umiejętne dobieranie formy przekazu do zdolności percepcyjnych słuchaczy, świadczy, że w dziele i nauczaniu Jezusa Chrystusa da się wypatrzeć określoną filozofię: określoną koncepcję bytu, poznania i działania, względnie spójną, która pozwala lepiej i dogłębniej zrozumieć samego Jezusa Chrystusa i Jego dzieło.

Przykładem, myślę, że dzisiaj aktualnym, jest kryjąca się za rozmowami Chrystusa z faryzeuszami na temat zachowania Prawa filozofia czy teoria prawa, rozwinięta zwłaszcza przez św. Pawła. Chrystus, wskazując np., że szabat jest dla człowieka, a nie człowiek dla szabatu (np. Mk 2,23-28), akcentował tym samym, że nie przepis prawny jest ostatecznym principium prawa, lecz człowiek i jego dobro. Łatwo zauważyć, że Chrystusowa koncepcja prawa zasadniczo różni się od współczesnych stanowisk, które z przepisu prawnego, więcej - z jego językowego zapisu, czynią absolut, jednocześnie zmieniając go $\mathrm{z}$ dnia na dzień przez rozmaite podmioty ustawodawcze. 
Nieuprawnione byłoby twierdzenie, że dzieło Jezusa Chrystusa, które jest podejmowane przez Kościół i duszpasterzy, jest oparte na jakimś systemie filozoficznym, znanym z historii filozofii. Natomiast - uważam - że da się w tym dziele wypatrzyć filozoficzne principia bytu, poznania i działania, których wyłuskanie i zrozumienie jest pracą filozoficzną. Aby tego dokonać, trzeba dogłębnie zrozumieć i zgłębić dzieło i osobę Jezusa Chrystusa, dokonać wglądu w to dzieło i osobę oraz uchwycić jego istotę, w czym nieodzowny jest filozoficzny trening, a w szczególności umiejętność dostrzegania istoty rzeczy, dociekania ostatecznych podstaw (principiów), dokonywania rozróżnień i systematyzowania.

\section{Filozofia w duszpasterstwie}

Filozoficzne principia bytu, poznania i działania, dostrzeżone w osobie i dziele Jezusa Chrystusa, są i poniekąd muszą być obecne w duszpasterstwie, czyli codziennym życiu Kościoła, gdzie dokonuje się nauczanie, kierowanie i uświęcanie. Orędzie zbawienia, któremu podporządkowane jest całe duszpasterstwo i cała pastoralna aktywność Kościoła, aby było skuteczne, tzn. aby doprowadziło ludzi do zbawienia, musi być przez człowieka przyjęte na miarę jego godności, czyli rozumnie i w sposób wolny. Dlatego Nowy Testament, a szczególnie św. Paweł, przestrzegał przed zwodniczymi mowami, powiemy - socjotechniką, która ze słuchaczy lub widzów czyni nierozumnych wyznawców $(1$ Kor 2,1). Przestrzegał też przed taką filozofią, która jest ,czczym oszustwem" (Kol 2,8), opartym tylko na ludzkiej tradycji, oraz przed tymi, którzy „nie rozumieją ani tego, co mówią, ani tego, o czym tak stanowczo twierdzą" (1 Tm 1,7). Przestroga aktualna, gdy spotykamy się z bełkotem i nieznajomością rzeczy w różnych dziedzinach, także $\mathrm{w}$ sprawach wiary i moralności, będących w centrum pracy duszpasterskiej. A jest to przecież przestroga wprost filozoficzna, oparta na fundamentalnym rozróżnieniu przedmiotu poznania i języka oraz na zrozumieniu jego istoty i funkcji.

Wykształcenie filozoficzne duszpasterza jest pomocne w prowadzeniu ludzi do Boga, podobnie jak jego znajomość szeroko rozumianej kultury i sztuki oraz nauk szczegółowych humanistycznych, społecznych i matematyczno-przyrodniczych. Pastoralność filozofii uwidacznia się zatem przede wszystkim w kształtowaniu duszpasterza jako człowieka światłego, mądrego i otwartego na świat współczesny w jego bogactwie, który to świat dzisiaj marginalizuje wiarę chrześcijańską i spycha ją w obszar subiektywnego światopoglądu i niepoważnych baśni. Jednocześnie filozofia daje duszpasterzowi narzędzia do dialogu z tym światem, często faktycznie niechrześcijańskim, któremu należy ukazać, że nauczanie Jezusa Chrystusa i Kościoła nie jest narracją wewnątrz- 
wyznaniową, lecz że jest obiektywne ważne, bo po prostu prawdziwe, gdyż taki jest świat i taki jest człowiek w całym swym bogactwie i złożoności.

Trzeba bowiem zdać sobie sprawę, że uzasadnienie wiary i jej treści poprzez wiarę jest błędnym kołem, gdyż to, co ma być uzasadnione, byłoby jednocześnie tego uzasadnieniem. To właśnie filozofia jest zdolna odsłonić tzw. praeambula fidei, które logicznie poprzedzają przyzwolenie wiary. Filozofia pozwala usprawiedliwić wiarę, wskazując, że z natury przynależy ona człowiekowi, że podstawowe prawdy wiary są dostępne ludzkiemu naturalnemu poznaniu, w następstwie czego uwiarygodnione zostają dane objawienia, także te, które są ścisłą tajemnicą wiary. Akt wiary religijnej wymaga bowiem przesłanek, racji, motywów i uzasadnienia, które explicite lub implicite są zawarte $\mathrm{w}$ objawieniu, lecz wymagają racjonalnego wydobycia i dostrzeżenia ich w rzeczywistości ludzkiej. Praeambula fidei to przede wszystkim naturalne, na podstawie świata stworzonego, poznanie istnienia Boga i niektórych Jego przymiotów, niewystarczalność bytu ludzkiego, a także naturalne uzasadnienie objawionych przez Boga zasad moralnych. Dlaczego zakaz bałwochwalstwa? - bo nierozumne, głupie, tzn. przeciwne mądrości jest uznawanie za Boga czegoś, co Bogiem nie jest. Dlaczego nakaz święcenia dnia świętego? - żeby praca ludzka, która jest narzędziem, środkiem, nie stała się celem, któremu zostaje podporządkowany człowiek; a że ten jest istotą społeczną, i świętowanie musi mieć wspólnotowy wymiar. Oto przykłady korzystania z filozofii w rozumieniu objawienia i jego przekazu.

\section{Filozofia w teologii}

Obecność filozofii w rozumieniu objawienia i jego przekazie ujawnia się jeszcze bardziej, gdy uczynimy z niego przedmiot metodycznie uporządkowanego poznania, czyli nauki o objawieniu, teologii.

Teologia, tak jak każda nauka, potrzebuje filozofii w krytycznym opracowaniu koncepcji jej badawczego postępowania, w określeniu jej przedmiotu, celu i metod, a także w ujawnieniu jej ontologicznych i epistemologicznych założeń. Dane objawienia, nawet dopełnione przez Tradycję (gdyby można ją było wypreparować z elementów filozoficznych), nie zastąpią w tym filozofii. Jest ona potrzebna przy formułowaniu problemów teologicznych, do trafnego i zasadnego stawiania pytań w świetle wiary, które to czynności domagają się uporządkowania danych objawienia i ich zhierarchizowania, uchwycenia ich istotnych treści i powiązań, co z kolei wymaga spełnienia istotowego wglądu w treści wiary.

Przede wszystkim jednak teologia potrzebuje filozofii jako instancji krytycznej w ocenie przeprowadzanych rozumowań, w określeniu statusu epi- 
stemologiczno-metodologicznego przyjmowanych przesłanek i konkluzji. W swym postępowaniu badawczym, przy zachowaniu swej specyfiki, teologia nie odbiega od innych dziedzin wiedzy naukowej. Różni ją od nich przede wszystkim przedmiot, jakim jest wiara objawiona, oraz to, że i swoje badania przeprowadza „w wierze”. Jak każda nauka dzięki naturalnym operacjom teoretyczno-poznawczym teologia ,zmierza do dociekliwej determinacji” swego przedmiotu, czyli tego, co objawione, oraz do jego „możliwie wszechstronnej eksplikacji" ". Wymaga to ustalenia dla niej teoretycznych terminów specyficznych, dzięki udziałowi zarówno wiedzy czysto naturalnej, w tym przede wszystkim - filozoficznej, jak i treści objawionych. Teologia, posługująca się wyłącznie terminami biblijnymi, byłaby jedynie opowiadaniem treści biblijnych i jako taka z konieczności musiałaby się wikłać w niejasności i sprzeczności. Gdy jako nauka zmierza do systematycznego ujęcia tych treści i możliwie jednoznacznego i precyzyjnego ich wyrażenia za pomocą pojęć ogólnych, czerpać je musi z innych dziedzin. Nietrudno wykazać, że takie terminy jak „natura”, „substancja”, „osoba”, „przeistoczenie”, „,nadprzyrodzone”, „łaska”, „sprawność”, „,czyn” nie występują w Biblii albo wcale, albo nie są terminami technicznymi, lecz zostały wypracowane przez filozofię i przejęte oraz zmodyfikowane przez teologię, choć niekiedy przez tego samego człowieka, który był zarówno filozofem, jak i teologiem. Ponadto teologia nie ogranicza się do usystematyzowania danych objawienia i ich zrozumienia, interpretacji, co byłoby swoistą racjonalizacją wiary, lecz w świetle wiary próbuje rozwikłać problemy, które ciągle i ciągle rodzą się w zmieniającej się współczesności, a które mają już teoretyczne umiejscowienie w różnych dziedzinach wiedzy. Stanisław Kamiński tę drogę postępowania teologii nazwał „rewelacjonizacją wiedzy przyrodzonej o całym życiu chrześcijańskim”, która polega na tym, że interpretuje się je w świetle szeroko pojętego objawienia, korzystając z przyrodzonej wiedzy o nim $^{5}$.

Najistotniejszą rolę odgrywa filozofia w samym dyskursie teologicznym poprzez włączenie weń tez rozumowych, mających najczęściej charakter filozoficzny, i poprzez sposób przeprowadzenia rozumowań. Różne dyscypliny teologiczne korzystają z różnych nauk, a im bardziej są oddalone od dyscyplin centralnych, jakimi są teologia dogmatyczna i fundamentalna oraz teologia moralna, tym bardziej ich związek z filozofią niknie na rzecz nauk pozytywnych, przede wszystkim humanistycznych i społecznych. Niemniej i w nich filozofia odgrywa doniosłą rolę poprzez kontrolowanie zasadności i poprawności teologicznego procesu poznawczego.

${ }^{4}$ S. Kamiński, Aparatura pojęciowa teologii a filozofia, w: tenże, Światopogląd, religia, teologia. Zagadnienia filozoficzne i metodologiczne, red. M. Walczak, A. Bronk, Lublin 1998, s. 46.

5 S. Kamiński, Wspótczesna teologia katolicka, w: tenże, Światopogląd, religia, teologia, dz. cyt., s. 147. 
Filozofia jest potrzebna teologii także po to, by ta mogła wchodzić w dia$\log \mathrm{z}$ innymi dziedzinami wiedzy oraz z kulturą niechrześcijańską. Zamknięta jedynie w wierze, mogłaby funkcjonować jedynie w wierze, czyli - inaczej mówiąc - być zrozumiała jedynie dla wierzących. Właśnie z racji obecności w teologii pierwiastka filozoficznego, może ona wykraczać poza siebie, nabierając charakteru uniwersalnego, i uczestniczyć w porozumieniu i dialogu z tymi, którzy nie wyznają wiary chrześcijańskiej.

\section{Pastoralność teologii fundamentem pastoralności filozofii}

Pastoralny wymiar filozofii zasadza się na pastoralności teologii, a ta ma swój fundament w pastoralnej naturze Kościoła. Teologia bowiem nie jest czymś autonomicznym, lecz - jak napisze Walter Kasper - ,jest funkcją Kościoła"6: powstaje w Kościele i służy Kościołowi, który ,jest w Chrystusie niejako sakramentem, czyli znakiem i narzędziem wewnętrznego zjednoczenia z Bogiem i jedności całego rodzaju ludzkiego" (KK 1).

Pastoralność Kościoła, a dalej - pastoralność teologii i filozofii w służbie Kościoła sprowadza się do służby człowiekowi, który dzięki pastoralnej pracy Kościoła ma zostać zbawiony. Istotę pastoralności Kościoła oddaje Gaudium et spes, a zwłaszcza jej pierwsze zdania: „Radość i nadzieja, smutek i trwoga ludzi współczesnych, zwłaszcza ubogich i wszystkich cierpiących, są też radością i nadzieją, smutkiem i trwogą uczniów Chrystusowych; i nie ma nic prawdziwie ludzkiego, co nie miałoby oddźwięku w ich sercu" (KDK 1). I dalej: „[...] Sobór, zaświadczając i wykładając wiarę całego ludu Bożego, zebranego w jedno przez Chrystusa, nie potrafi wymowniej okazać swojej solidarności, szacunku i miłości dla całej rodziny ludzkiej, w którą jest wszczepiony, jak nawiązując z nią dialog na temat owych różnych problemów, przynosząc światło czerpane z Ewangelii [...]" (KDK 3).

Przytoczone fragmenty nauczania soborowego uwidaczniają, że pastoralność teologii w żadnej mierze nie wyklucza jej teoretycznego, doktrynalnego charakteru, co więcej: zakłada go, a nawet prawdę Ewangelii czyni par excellence pastoralną, a co za tym idzie - upastoralnia filozofię, która służy teologii, a poprzez nią człowiekowi, ku któremu Kościół zwraca się z orędziem zbawienia. Jest to oczywiste, zwłaszcza że pierwszym i naczelnym pastoralnym zadaniem Kościoła jest nauczanie, a to zakłada u nauczającego wiedzę o tym, czego naucza, umiejętność argumentowania, tłumaczenia itp. Niestety, ta oczywistość, wynikająca z samej natury Kościoła, nie dla wszystkich była i jest tak oczywista. Zdawał sobie z tego sprawę kard. Karol Wojtyła, pisząc studium

\footnotetext{
${ }^{6}$ W. Kasper, Die Methoden der Dogmatik. Einheit und Vielheit, München 1967, s. 19.
} 
o realizacji soboru, i dlatego zaraz na wstępie dostrzegł potrzebę wskazania na komplementarność doktrynalności i pastoralności wobec - zapewne już dlań widocznych - tendencji przeciwstawiania ich sobie.

Zauważmy i podkreślmy: kard. Wojtyła zasadniczy postulat realizacji soboru widzi we ,wzbogaceniu wiary”. Stąd pisze:

W świetle zamierzenia Vaticanum II, który chciał być przede wszystkim Soborem duszpasterskim, pastoralnym, musimy też spojrzeć na nasz postulat wzbogacenia wiary, który stawiamy u podstaw wszelkiej realizacji Soboru, wszelkiej odnowy. Można powiedzieć, że każdy Sobór w dziejach Kościoła był duszpasterski, choćby z tego powodu, że zgromadzeni na nim pod przewodnictwem papieża biskupi, są pasterzami Kościoła. Równocześnie każdy Sobór jest aktem najwyższego w Kościele Magisterium. Magisterium oznacza nauczanie, które jest posłannictwem Apostołów oraz ich następców, jest ich udziałem i funkcją. Nauczanie to w swej istotnej treści dotyczy spraw wiary i moralności: w co i jak wierzyć i jak wedle tej wiary żyć. Nauka wiary i moralności (doctrina fidei et morum) stanowi treść nauczania Pasterzy Kościoła, co sprawia, że akty Magisterium o charakterze doktrynalnym mają zarazem znaczenie pastoralne, akty zaś o charakterze pastoralnym - poprzez zakorzenienie w nauce wiary i moralności - mają zarazem znaczenie doktrynalne. [...] Znajduje to wybitne potwierdzenie w Vaticanum II, który zachowując charakter duszpasterski - owszem, ze względu na swój duszpasterski cel - rozwinął bardzo szeroko naukę wiary, przez co też stworzył podstawy jej wzbogacenia ${ }^{7}$.

W istocie ta sama myśl została powtórzona przez Jana Pawła II np. w jego Liście apostolskim Tertio millennio adveniente (42), gdzie czytamy:

Wszystko powinno zmierzać ku pierwszoplanowemu celowi Jubileuszu, jakim jest ożywienie wiary i świadectwa chrześcijan. [...] Pierwszy rok będzie zatem czasem sprzyjającym ponownemu odkryciu kat e ch e zy - jej pierwotnego sensu i wartości jako „nauki Apostołów” (por. Dz 2,42) o osobie Jezusa Chrystusa i o Jego tajemnicy zbawienia. Bardzo przydatne będzie tu pogłębione studium Katechizmu Kościoła Katolickiego $[\ldots]^{8}$.

To, co zostało wyżej powiedziane, skłania zatem do spojrzenia na postulat pastoralności teologii nie jako na jeszcze jedno, szczegółowe wskazanie, postawione obok ubiblijnienia, historyczności, chrysto- i antropocentryzmu, lecz jako na postulat podstawowy, w którym pozostałe mają swój fundament. Dostrzeżenie zaś pastoralności teologii katolickiej w ogóle, w tym jej dyscy-

\footnotetext{
${ }^{7}$ K. Wojtyła, U podstaw odnowy. Studium o realizacji Vaticanum II, Kraków 1972, s. 12-13.

8 Jan Paweł II, Tertio millenio adveniente, http://www.opoka.org.pl/biblioteka/W/WP/ jan_pawel_ii/listy/tertio.html [dostęp: 08.05.2017].
} 
plin teoretycznych (dogmatyki, teologii fundamentalnej, teologii moralnej), wskazuje także na pastoralny wymiar filozofii, z której kompetencji teologia korzysta.

$* * *$

Dostrzegając różnoraką obecność filozofii w pastoralnej posłudze Kościoła, a jednocześnie wyraźnie rozróżniając zbawczą jego misję od czysto poznawczych zadań, jakie stawia sobie filozofia, można uwidocznić jej służebną rolę wobec posługi Kościoła, a dalej wobec życia każdego człowieka. Filozofia bowiem w jakiejś mierze przynależy do natury człowieka, który pyta wyraźnie czy niewyraźnie o podstawy swego bytu, poznania i działania, o podstawy swojej wiedzy i wiary religijnej. W służbie temu człowiekowi Kościół, który odpowiada na te pytania, sięgając do objawienia, nie może nie dostrzegać ich filozoficznego aspektu. Dlatego w posłudze swej, w działalności pastoralnej, trzeba także sięgać po filozofię jako mądrą służebnicę.

\section{PASTORAL DIMENSION OF PHILOSOPHY}

\section{Summary}

The pastoral dimension of philosophy manifests itself in the service of truth which becomes part of the mission of the Church. It is revealed in the work of Jesus Christ, in the Church's pastoral endeavours and in theology. The role of philosophy in the mission of the Church is ancillary and necessary at the same time, as it helps to answer man's questions about the meaning of his/her being, cognition and action, the foundation of his/her knowledge and faith.

Keywords: philosophy; pastoral mission of the Church

Słowa kluczowe: filozofia; pastoralne posłannictwo Kościoła

\section{BIBLIOGRAFIA}

Jan Paweł II, Tertio millenio adveniente, http:/www.opoka.org.pl/biblioteka/W/WP/jan_pawel_ii/ listy/tertio.html [dostęp: 08.05.2017].

Kamiński S,. Światopoglą, religia, teologia. Zagadnienia filozoficzne i metodologiczne, red. M. Walczak, A. Bronk, Towarzystwo Naukowe KUL, Lublin 1998. 
Kasper W., Die Methoden der Dogmatik. Einheit und Vielheit, Kösel Verlag, München 1967.

Krokos J., Czy filozofia jest potrzebna teologii, w: $W$ wierności Kościolowi. Księga pamiątkowa dedykowana Józefowi Kardynałowi Glempowi Prymasowi Polski w 80. rocznicę urodzin, red. M. Kreczmański, H. Małecki, Wydawnictwo Archidiecezji Warszawskiej, Warszawa 2009, s. $227-236$.

Pierwsi apologeci greccy, oprac. J. Naumowicz, tłum. L. Misiarczyk, Wydawnictwo M, Kraków 2004.

Wojtyła K., U podstaw odnowy. Studium o realizacji Vaticanum II, Polskie Towarzystwo Teologiczne, Kraków 1972.

JAN KROKOS - prof. dr hab., kierownik katedry teorii poznania na Wydziale Filozofii Chrześcijańskiej UKSW, autor m.in. książek: Fenomenologia Edmunda Husserla, Aleksandra Pfändera i Maxa Schelera, Sumienie jako poznanie, Odsłanianie intencjonalności. 